\title{
The Right to Autonomy as a Moral Foundation for the Realization Principle in Income Taxation
}

\author{
Charles Delmotte
}

The work of Thomas Piketty has engendered a twofold change in the economic viewpoint of many academics, policymakers, and laymen. Not only did his empirical analyses lead to a revitalization of the relevance of relative inequality, but his Capital in the Twenty-First Century also opened up a debate on tax justice. Given the accumulating nature of capital unravelled by Piketty, two tax measures are championed to decelerate the increasing wealth gap. In addition to wealth taxes-that is, levies imposed on the market value of one's fortune-Piketty delivers arguments for increasing the taxation of capital gains.

Given this greatly increased public interest in the taxation of capital, the present chapter supplements the debate on the ideal capital gains tax through its examination of a suitable technique for assessing income. On the one hand, one's assets can be taxed according to the annual increase in market value (the mark-to-market approach). On the other hand, the taxation of capital can be imposed on the income that one realizes from one's assets-the monetary benefits received in exchange for a transfer of property (the realization approach). Importantly, tax scholars quasi-unanimously decry the former practice in terms of equity and efficiency. Theoretically, the (diminishing) acceptance of the taxation of realized gains is merely founded on pragmatic concerns.

I will show that the taxation of realized gains is by no means an unfounded principle. Departing from a normative appreciation of each person having a specific end of his or her own, I will outline the problematic nature of the mark-to-market approach. In particular, I will exemplify that when we take general market prices as the basis for interpersonal comparisons-that is, to assess peoples' incomes-we violate people's autonomy. Specifically, the automatic attribution of market value underlying a markto-market approach measures people's incomes with standards and valorizations that are alien to their own views. The value of a realization-based tax lies exactly in the fact that such taxation replicates people's own valorizations, expressed in their confirmation of a particular price within an agreement (such as a sale).

By delivering a deontological defence of the realization principle, the current contribution intends to:

1. Establish a possible normative foundation for this theoretically denounced practice, and 
2. Supplement the debate on tax reform by suggesting the promotion of efficiency or redistribution in an autonomy-friendly fashion.

\section{Thomas Piketty and the Manifestation of Relative Inequality}

There are two basic normative assessments for an economic distribution. The first analyses peoples' absolute level of welfare. One approach states that what matters is not that people have the same level of income or wealth, but rather that they have enough, according to some standard of sufficiency. ${ }^{1}$ The prioritarian tradition aims higher and states that we should target economic distributions that maximize the level of the least well-off. ${ }^{2}$ When judging a particular economic situation, an underlying system is valued positively if it benefits those who are worst off more than an alternative system does, in terms of some particular standard. ${ }^{3}$ A third application targets the maximization of welfare gains, without any particular regard for the distribution between persons. ${ }^{4}$

An alternative way of scrutinizing a specific distribution uses relative terms-that is, it does not matter how much people have; what matters is their economic relation. To judge a situation we do not look at what level of welfare people attain; what is important is whether others have more or less than they have. ${ }^{5}$ A situation will be deemed to be positive if the differences between people's holdings are small, and deemed to be negative if there are huge differences between people's holdings. ${ }^{6}$

Applied to income-the accretion of wealth-the following comparison of alternative social situations can trigger our proper intuitions regarding the matter:

\begin{tabular}{ll}
\hline Society A & Society B \\
\hline Richest $10 \%$ earn $£ 30,000$ per year & Richest $10 \%$ earn $£ 100,000$ per year \\
Poorest $10 \%$ earn $£ 10,000$ per year & Poorest $10 \%$ earn $£ 20,000$ per year \\
\hline
\end{tabular}

\footnotetext{
${ }^{1}$ A sufficientarian approach to social justice can be found in: Harry Frankfurt, 'Equality as a Moral Ideal', in Harry Frankfurt (ed.), The Importance of What We Care About: Philosophical Essays (Cambridge: Cambridge University Press, 1988), 134-58.

${ }^{2}$ The most famous variant of the 'prioritarian standard' was established by John Rawls's maximin principle, arguing that justice demands maximizing the primary goods for the worst off with in society. See John Rawls, Theory of Justice (Oxford: Oxford University Press, 1978), 152-6.

${ }^{3}$ A recent defence of social justice's primary aim to maximize welfare gains for the least well-off can be found in: John Tomasi, Free Market Fairness (Princeton: Princeton University Press, 2012).

${ }^{4}$ This is what is classically understood under (outcome) utilitarianism. See Amartya Sen, 'Utilitarianism and Welfarism', 76(9) The Journal of Philosophy (1979) 468.

${ }^{5}$ Such a position is defended by, for example, Larry Temkin in: 'Equality, Priority, and the Levelling Down Objection', in Matthew Clayton and Andrew Williams (eds), The Ideal of Equality (Houndmills: Macmillan, 2000), 126-61. Many other political philosophers defend such a comparative view on equality, albeit one that is limited in scope. Welfare inequality between persons is deemed principally wrong, but only to the extent that it is caused by inequality of endowment or opportunity for welfare. See Ronald Dworkin, 'What Is Equality? Part 2: Equality of Resources', 10(4) Philosophy \& Public Affairs (1981) 283345; John Roemer, 'A Pragmatic Theory of Responsibility for the Egalitarian Planner', 22(2) Philosophy \& Public Affairs (1993) 146-66.

${ }^{6}$ Such a form of egalitarianism is discussed by Derek Parfitt in: 'Equality and Priority', 10(3) Ratio (1997) 202-21.
} 
Some of us will intuitively opt for Society B as being the preferred situation, if we focus on absolute figures: a prioritarian approach would value Society B for yielding the most benefit for the least well-off, and a utilitarian approach would value it for generating the most overall welfare. Within this framework it does not matter that the richest 10 per cent own more than 80 per cent of the assets of Society B; what matters is how well off 'the poor' are, or how well off society as a whole is in terms of absolute numbers.

Others will opt for a strict egalitarian standard, and will choose Society A as the preferred situation. What people have is only relevant with respect to how much others have, and our final goal is to mitigate inequalities. Within this framework it does not matter that the poorest 10 per cent are above a certain standard of living and able to acquire a decent income; what matters is that the richest 10 per cent do not earn five times as much as them. Equality thus has value in itself.

Although for many years the International Monetary Fund (IMF), the World Bank, and almost all Western leaders promoted economic growth, and consequently focused on welfare gains in absolute numbers as a normative evaluation for an economic system, the ideal of maximizing standards and absolute numbers is currently fading. In the aftermath of the financial crisis in the first decade of this century, public attention shifted from a focus on growth and absolute welfare gains to an analysis of the distributive character of economic gains in relative terms. Many popular contributions have addressed this issue in terms of what part of 'the pie' goes to which percentile, confirming the relevancy of a notion of relative inequality. ${ }^{7}$ It is significant that public authorities mirror this moral conversion and express political indignation at huge economic gaps. President Obama stated that 'the basic bargain at the heart of our economy has frayed' in response to the fact that the top 10 per cent of the population in the United States yields 50 per cent of the national income. ${ }^{8}$ Furthermore, at the World Economic Forum (WEF) this year the subject of relative economic inequality was promoted as the core topic and the preferred economic prism, thus dethroning the notion of a maximizing analysis. ${ }^{9}$ Prior to this, the IMF had already launched the idea of 'inclusive capitalism', aiming at a better distribution of profits between the members of society. ${ }^{10}$

\footnotetext{
7 An illustration of the growing public importance of relative inequality can be found in: Danny Dorling, 'Growing Wealth Inequality in the UK is a Ticking Timebomb', The Guardian (15 October 2014), http://www.theguardian.com/commentisfree/2014/oct/15/wealth-inequality-uk-ticking-timebombcredit-suisse-crash; Stewart Lansley, 'Why Economic Inequality Leads to Collapse', The Guardian (5 February 2012), http://www.theguardian.com/business/2012/feb/05/inequality-leads-to-economiccollapse; Christopher Ingraham, 'If You Thought Income Inequality Was Bad, Get a Load of Wealth Inequality', The Washington Post (21 May 2015), https://www.washingtonpost.com/news/wonk/wp/2015/ 05/21/the-top-10-of-americans-own-76-of-the-stuff-and-its-dragging-our-economy-down/; Michael Fletcher, 'White People Have 13 Dollars for Every Dollar Held by Black Americans', The Washington Post (12 December 2015), https://www.washingtonpost.com/news/wonk/wp/2015/05/21/the-top-10-ofamericans-own-76-of-the-stuff-and-its-dragging-our-economy-down/.

${ }^{8}$ Remarks by the President on Economic Mobility, Whitehouse.gov (4 December 2013), http://www. whitehouse.gov/the-press-office/2013/12/04/remarks-president-economic-mobility.

9 See World Economic Forum, Report 2015, 'Top 10 Trends 2015', http://reports.weforum.org/outlookglobal-agenda-2015/top-10-trends-of-2015.

${ }^{10}$ See Christine Lagarde, 'Economic Inclusion and Financial Integrity-an Address to the Conference on Inclusive Capitalism’ (27 May 2014), https://www.imf.org/external/np/speeches/2014/052714.htm.
} 
Among many factors, the revival of an egalitarian normative outlook was certainly caused by a series of studies informing us of a tendency towards the accumulation of wealth and income in the hands of a few over the last few decades. The Organization for Economic Co-operation and Development (OECD) recently reported a concentration of wealth since the 1970s, and found that since around the year 2000 in many Western countries the bottom 50 per cent of the population has been holding a small fraction of the national wealth, while the top 10 per cent often holds about 50 per cent of it. ${ }^{11}$ Credit Suisse confirms this observation and has identified a concentration of wealth over the last 40 years, when the relative share for the top 10 per cent started rising in the United States, in eight European countries, and in Australia. ${ }^{12}$ Concerning the highly correlated issue of income inequality, the OECD found that the gap has never been so high: in its member countries today, the richest 10 per cent have an income 9.5 times the size of the poorest 10 per cent, whereas this ratio was only 7.1 in $1980 .{ }^{13}$ Davies et al. confirm this concentration of wealth, and estimate on the basis of research in thirty-nine countries that the top 10 per cent of the population in 2000 held 71 per cent of all holdings. ${ }^{14}$ Last but not least, Piketty's research in Capital in the Twenty-First Century certainly corroborates this current normative transition, revealing that for many Western countries, since the 1970s the top 10 per cent-and certainly the top 1 per cent-are holding an increasing proportion of national wealth. ${ }^{15}$

Piketty provides us not only with numbers but also with a causal analysis of the growing inequality of wealth, which together form an important empirical justification for certain theoretical (fiscal) measures that can oppose this trend. ${ }^{16}$ The central thesis of his book is that over the last forty years the return on capital-by which Piketty means income from stocks, bonds, participations, shares, annuities, intangible assets, and real estate-has exceeded public economic growth. ${ }^{17}$ This explains why wage earners have seen their wealth accrue to much smaller proportions than that of the capital owners; capital is highly unequally distributed andgiven its cumulative nature-it is getting progressively more so. This corresponds with the findings of the Global Wealth Report, which emphasizes the correlation between the capital assets of a household and its wealth level. ${ }^{18}$ Furthermore, the

\footnotetext{
${ }^{11}$ Kaja Bonesmo Fredriksen, 'Less Income Inequality and More Growth-Are they Compatible? Part 6. The Distribution of Wealth', OECD Economics Department Working Papers, No. 929, OECD Publishing 2012, 5-6.

${ }^{12}$ Credit Suisse, Global Wealth Report 2014, https://www.credit-suisse.com/uk/en/news-andexpertise/research/credit-suisse-research-institute/publications.html, 37.

${ }^{13}$ Federico Cingano, 'Trends in Income Inequality and Its Impact on Economic Growth', OECD Social, Employment and Migration Working Papers, No. 163, OECD Publishing 2014, http://dx.doi.org/ 10.1787/5jxrjncwxv6j-en, 9.

${ }^{14}$ James Davies, Susanna Sandström, Anthony Shorrocks, and Edward Wolf, 'The Level and Distribution of Global Household Wealth', 121(551) The Economic Journal (March 2011) 250.

15 Piketty delivers evidence for a widening wealth gap in the countries for which sufficient information was available, such as Sweden, the United Kingdom, France, and the United States. See Thomas Piketty, Capital in the Twenty-First Century, Arthur Goldhammer (trans.) (Cambridge: Belknap, 2014), ch. 10; see Figures 10.1-10.5.

16 See Section II for some redistributive measures in response to Piketty's observation.

17 Piketty, n. 15, ch. 6. For Piketty's definition of capital (income), see Ibid., 18.

18 Global Wealth Report 2014, n. 12, 34.
} 
OECD points in the same direction, showing a noticeable effect of inclusion of capital gains on the share of the top 1 per cent of incomes in countries for which information was available. ${ }^{19}$ This further coincides with the findings of Davies, which indicates that a disproportionate number of high incomes are derived from capital assets. ${ }^{20}$

We can thus observe the manifestation of economic inequality on two levels. First, empirically speaking, wealth is unequally distributed, and a tendency towards greater inequality can be observed in many Western countries. Capital plays a key role in this evolution, yielding relatively high revenues when compared with labour, leading to a concentration of wealth. Second, normatively speaking, by underwriting the problematic nature of this evolution, academics and public discourse are-often implicitlyadhering to an egalitarian standard, as they are confirming economic inequality to be intrinsically bad.

This development in economic philosophy cannot be perceived as an isolated matter-Piketty's analysis of relative inequality has already sparked a widespread debate on the political measures that should be taken, especially with regard to the key role that taxation should play. ${ }^{21}$ Moreover, if taxation is supposed to be levied in accordance with the ability to pay, Piketty has raised awareness of tax codes' failure to reach capital owners. ${ }^{22}$ In the light of current economic inequality, Piketty and others underline how current policies exacerbate this effect, and highlight the preferential treatment of capital income. ${ }^{23}$

19 OECD, Divided We Stand: Why Inequality Keeps Rising (Paris: OECD Publishing, 2011), 349, 359.

${ }^{20}$ James B. Davies, 'Wealth and Economic Inequality', in Wiemer Salverda, Brian Nolan, and Timothy M. Smeeding (eds), The Oxford Handbook of Economic Inequality (Oxford: Oxford University Press, 2009), 137.

${ }^{21}$ In response to the regained interest in taxation from the prism of relative inequality, the New York University School of Law and the UCLA School of Law hosted a symposium on Capital in the TwentyFirst Century on 4 October 2014, with the papers being published in the Tax Law Review in 2015. Another illustration of tax scholars' reaction is: Paul Caron and James Repetti, 'Occupy the Tax Code: Using the Estate Tax to Reduce Inequality and Spur Economic Growth', 40(5) Pepperdine Law Review (2013): 125590. See also Paul Caron, 'Thomas Piketty and Inequality: Legal Causes and Tax Solutions', 64 Emory Law Journal Online (2015) 2072-82; Shi-Ling Hsu, 'The Rise and Rise of the One Percent: Considering Legal Causes of Wealth Inequality', 64 Emory Law Journal Online (2015) 2043-72.

${ }^{22}$ Among other things, Piketty mentions low tax rates for capital income (and a decrease in progressive rates) as one of the factors causing growing wealth inequality. See Piketty, n. 15, ch. 14, 495-6.

${ }^{23}$ See, for example, Davies, n. 20, 143, in which he states: 'lower capital gains taxes seen in many countries since "supply side" reforms began in the Reagan/Thatcher years, have apparently made accumulation easier for the rich.' Martin J. McMahon, Jr confirms the role of the US tax system in the light of economic inequality; see Martin J. McMahon, Jr, 'The Matthew Effect and Federal Taxation', 45(5) Boston College Law Review (2004) 993-1128. Kaja Bonesmo Fredriksen also mentions the role of tax systems in enhancing inequality because of the preferential treatment of capital; see Kaja Bonesmo Fredriksen, n. 11, 16-18. Peter Hoeller et al. indicate the declining top income tax rates and the preferred treatment of capital gains as causes of inequality; see Peter Hoeller et al., 'Less Income Inequality and More GrowthAre they Compatible? Part 4, Top Incomes', OECD Economics Department Working Papers 927 (2012), http://dx.doi.org/10.1787/5k9h28wm6qmn-en, 9-11. For a technical critique on the current preferential tax treatment of capital gains, see Deborah Schenk, 'Saving the Income Tax with a Wealth Tax', 53(3) Tax Law Review (2000) 423-76. 


\section{Taxation of Capital and the Mark-to-Market Ideal in Income Tax Theory}

Piketty thus triggered a debate on tax justice, causing politicians, organizations, and academics alike to examine measures to increase the fiscal burden on the wealthy. The debate has specifically revolved around examining various measures that could be upheld to increase fiscal contributions from capital owners. In order to conduct a specific analysis of tax justice, at least three different types of taxation of capital should be distinguished.

In order to overcome 'the indefinite increase of inequality of wealth', Piketty himself proposes the first type, the wealth tax: a levy on the value of one's holdings, irrespective of whether any revenue is being gained. In the absence of any transaction, a wealth tax is ideally levied on the market value of one's assets. ${ }^{24}$

Another possibility for targeting accumulative capital is to increase the taxation of revenue. Rather than taxing one's holdings, a capital gains tax is a form of income taxation, targeting only the gains that one's assets yield. ${ }^{25}$ Capital gains taxation can take two forms depending on how income is assessed-and taxed.

One is the market-to-market capitals gains tax, which constitutes the second form of taxation of capital. This measure will tax capital as it accrues, and accordingly targets the annual increase in market value of one's holdings. The event that constitutes

\footnotetext{
${ }^{24}$ Limited forms of this wealth tax exist in many countries. For more information see Moris Lehner, 'The European Experience with a Wealth Tax: A Comparative Discussion', 53(615) Tax Law Review (1999-2000) 617-692. Piketty, however, endorses a global and universal wealth tax, which includes not only real estate but also all the components of capital, such as stocks, bonds, participations, shares pensions, annuities, intangible assets, and real estate; see Piketty, n. 15, 517. Such taxes exist in France and were, for example, proposed by the Belgian Francophone Socialist Party (PS), who brought a wealth tax bill into parliament to address the growing inequality; see Parti Socialiste, Proposition de Loi Visant à introduire un impôt sur les grands patrimoines (13 January 2015), www.dekamer.be/flwb/pdf/54/0770/ 54K0770001.pdf. For academic elaborations on wealth taxes in the light of inequality, see James Repetti, 'Democracy, Taxes, and Wealth', 76(3) New York University Law Review (2001) 825-73; Maureen Maloney, 'Distributive Justice: That is the Wealth Tax Issue', 20(3) Ottawa Law Review (1988) 601-35. An analysis of wealth taxation as an effective measure to tax capital gains is delivered in Schenk, n. 23, 423-76. From a different angle, see Stefan Bach et al., 'A Wealth Tax on the Rich to Bring Down Public Debt? Revenue and Distributional Effects of a Capital Levy in Germany', 35(1) Fiscal Studies (2014) 67-89.

${ }^{25}$ Several academics discuss the increased taxation of capital gains with reference to economic inequality. For instance, Piketty criticizes the decrease of capital gains' tax in many Western countries (see Piketty, n. 15, 495-6). Bankman and Shaviro also mention a surtax on capital income as the main candidate to mitigate wealth inequality; see Joseph Bankman and Daniel Shaviro, 'Piketty in America: A Tale of Two Literatures', 68(3) Tax Law Review (2015) 505. [Wijtvliet also champions the higher taxation of capital gains as an appropriate measure to mitigate wealth inequality; see Laurens Wijtvliet, 'Too Little, Too Late: The Uneasy Case for a Wealth Tax as a Means to Mitigate Inequality', 42(10) Intertax (2014) 642. Economists also propose that an increase in capital gains taxation-in the form of an equal taxation of income-is necessary in the light of equity and efficiency; see James Mirlees et al., 'The Mirrlees Review: Conclusions and Recommendations for Reform', 32(3) Fiscal Studies (2011) 331-59; Peter Diamond and Emmanuel Saez, 'The Case for a Progressive Tax: From Basic Research to Policy Recommendations', 25(4) Journal of Economic Perspectives (2011) 165-90. Such a tax shift was, for example, proposed by the OECD for Belgium; see OECD, Economic Survey of Belgium (February 2015), http://www.oecd.org/belgium/economic-survey-belgium.htm. President Obama also advanced an increase in capital gains taxation, up to 28 per cent; see Briefing Room, Press Release, The White House (17 January 2015), https://www.whitehouse.gov/the-press-office/2015/01/17/ fact-sheet-simpler-fairer-tax-code-responsibly-invests-middle-class-fami.
} 
taxation is thus the passing of a year and the increase in market value. This tax resembles the wealth tax in its assessment technique of focusing on the market value, but it remains an income tax nonetheless; a decrease in market value for a specific period will exclude taxation.

Finally, there is the realization-based capital gains tax, the third form of taxation of capital. Unlike the previous form of income taxation, which simply taxes value fluctuations, this measure presupposes the occurrence of a realization event, being the sale or exchange of an asset. The event that constitutes taxation is thus (agreement on) the receipt of a benefit (normally money) in exchange for the transfer of property. Both are income taxes and aim only to tax gains.

Within the theoretical distinction outlined above, this chapter deals primarily with the last two forms of taxation. The general increased interest in tax justice will thus be compressed to the issue of the taxation of capital income. To the extent that growing wealth inequality is caused by capital income and exacerbated by its preferential fiscal treatment, a primary solution appears to be increasing the use of the capital gains tax. ${ }^{26}$

Prior to any general increase in tax rates, one has to outline a particular conception of income. When do stocks, bonds, participations, shares, pensions, annuities, intangible assets, and real estate yield an income? Given the continued acceptance of-and renewed interest for-an income tax, one can detect a normative chasm in terms of which of the above-mentioned standards should apply in income taxation.

Most parts of current tax codes, and people's common intuitions alike, support the realization approach: income is the receipt-or at least a legal agreement over the receipt-of a tangible benefit. ${ }^{27}$ Consequently, one should only be taxed when actually receiving contemporaneous benefits from a sale or exchange of property, or at least agreeing to such a receipt.

In contrast, taxation theory defines income as the sum of (1) the market value of rights exercised in consumption, and (2) the change in the value of the store of property rights between the beginning and end of the period in question. ${ }^{28}$ This latter view on income includes the accretion of capital, and it consequently allows authorities to tax any increase in the market value of one's assets, irrespective of the occurrence of a sale or exchange. ${ }^{29}$ Following this definition, scholars working in the field of income

\footnotetext{
26 See Bankman and Shaviro, n. 25, 505; Wijtvliet, n. 25, 642.

${ }^{27}$ See, for example, Jeffrey L. Kwall, 'When Should Asset Appreciation Be Taxed? The Case for a Disposition Standard of Realization', 86(1) Indiana Law Review (2011) 79. People generally oppose a conception that follows the mark-to-market approach, since income is commonly conceived as an actual receipt, while an increase in value is regarded as a mere 'paper gain'; see Deborah Schenk, 'A Positive Account of the Realization Rule', 57(3) Tax Law Review (2004) 377.

${ }^{28}$ This highly influential definition is often called the 'Haig-Simons' concept of income, after Henry C. Simons and Robert Haig; see Henry Simons, Personal Income Taxation: The Definition of Income as a Problem of Fiscal Policy (Chicago: University of Chicago Press, 1938), 49-50; Robert Murray Haig, 'The Concept of Income-Economic and Legal Aspects', in Robert Murray Haig (ed.), The Federal Income Tax (New York: Columbia University Press, 1921), 27.

${ }_{29}$ The so-called Haig-Simmons concept of income logically justifies a mark-to-market tax; see, for example, John Robert H. Scarborough, 'Different Rules for Different Players and Products: The Patchwork Taxation of Derivatives', 72(12) Taxes (1994) 1031-49; Deborah H. Schenk, 'Taxation of Equity Derivatives: A Partial Integration Proposal', 50(4) Tax Law Review (1995) 571-642; John B. Shoven and Paul Taubman, 'Saving, Capital Income, and Taxation', in Henry J. Aaron and Michael J. Boskin
} 
taxation embrace the mark-to-market approach as an ideal assessment method. ${ }^{30}$ Whether or not one monetizes an increase of 10 per cent of one's fortune is of no importance to the ideal income tax. As income occurs with accretion, taxation merely demands an increase in market value.

Tax theory discerns the continued application of the realization principle in existing tax codes as 'the basic defect' of income taxation, and no serious scholar seems to ascribe it any normative foundation. ${ }^{31}$ Vilified for reasons of both equity and efficiency, the 'Achilles' heel of the income tax' even led a group of tax scholars to support a shift in tax base. ${ }^{32}$ In particular, an impressive amount of contributions have criticized the 'deferral' of the taxation of economic gains until realization, for creating substantial investment distortions and inefficiencies. ${ }^{33}$ More specifically, the literature points at taxpayers' ability to manipulate their tax debt under the realization principle. In this sense the realization-based approach can be pinpointed as one of the elements causing inequality, as it enables capital owners to circumvent their tax duties. Imposing taxation only when investments generate gains leaves the possibility of debtfinanced consumption, strategic trading, the strategic timing of asset dispositions, and portfolio adjustments for financial investments. ${ }^{34}$

Furthermore, the realization principle also conflicts with the traditional aims of equity, as it fails to treat different sources of income equally. ${ }^{35}$ Once one adheres to the view that economic advantages for assets rise with the increase of their market value,

(eds), The Economics of Taxation (Washington, DC: Brookings Institute, 1980), 211-13; Reed Shuldiner, 'Consistency and the Taxation of Financial Products', 70(12) Taxes (1992) 781-93.

30 Fred B. Brown, “"Complete” Accrual Taxation', 33(4) San Diego Law Review (1996) 1559-680; David J. Shakow, 'Taxation without Realization: A Proposal for Accrual Taxation', 134(5) University of Pennsylvania Law Review (1986) 1111-205.

${ }^{31}$ See, for example, William D. Andrews, 'The Achilles Heel of the Comprehensive Income Tax', in Charles E. Walker and Mark A. Bloomfield (eds), New Directions in Federal Tax Policy for the 1980s (Cambridge, MA: Ballinger, 1983), 278 (identifying the realization principle as one of the main culprits for the failure to adhere to a comprehensive income tax ideal); Gerard M. Brannon, 'Tax Loopholes as Original Sin: Lessons from Tax History', 31(6) Villanova Law Review (1986) 1763-85; and for a recent confirmation see Edward J. McCaffery, 'A New Understanding of Tax', 103(5) Michigan Law Review (2005) 889, in which he states: 'The realization requirement destroys the source of neutrality of an ideal income tax.'

${ }^{32}$ Most tax scholars see a possibility in obtaining a consumption tax; see Joseph Bankman and David Weisbach, 'Consumption Taxation Is Still Superior to Income Taxation', 60(3) Stanford Law Review (2007) 789-803; Daniel N. Shaviro, 'Replacing the Income Tax with a Progressive Consumption Tax', 103 Tax Notes (2004) 91-113.

${ }^{33}$ Brown, n. 30, 1559; Noel B. Cunningham and Deborah H. Schenk, 'Taxation without Realization: A “Revolutionary" Approach to Ownership', 47(4) Tax Law Review (1992) 725-814; Daniel Halperin, 'Saving the Income Tax: An Agenda for Research', 77 Tax Notes (1997): 967-77; Stephen B. Land, 'Defeating Deferral: A Proposal for Retrospective Taxation', 52(1) Tax Law Review (1996): 45-118; David M. Schizer, 'Realization as Subsidy', 73 New York University Law Review (1998) 1549-626; David A. Weisbach, 'A Partial Mark-to-Market Tax System', 53(1) Tax Law Review (1999), 95-136.

${ }_{34}$ On debt-financed consumption, see McCaffery, n. 31, 888. On strategic trading see David Elkins, 'The Myth of Realization: Mark-to-Market Taxation of Publicly-Traded Securities', 10(5) Florida Tax Review (2010) 375-407; Mark P. Gergen, 'The Effects of Price Volatility and Strategic Trading under Realization, Expected Return and Retrospective Taxation', 49(2) Tax Law Review (1994) 209-68. On timing see Myron Scholes et al., Taxes and Business Strategy: A Planning Approach (Upper Saddle River: Prentice Hall, 2009), 185-9. On portfolio adjustments see Bankman and Shaviro, n. 25, 477-85; Schenk, n. $27,426-35$.

${ }^{35}$ Ibid., 93; Kwall, n. 27, 93. 
a realization-based tax can be seen as ignoring vital increases in one's well-being. The deferral of taxation until the moment of receipt is thus presented as a tax benefit in favour of capital. ${ }^{36}$ Reluctance to tax capital as it fluctuates primarily benefits those whose assets contain capital, and this contributes to economic inequality. ${ }^{37}$

As hard as it will be to find a principled defence for the realization principle, many tax scholars do grant it some pragmatic support. ${ }^{38}$ As expressed in the seminal work of Robert Haig, the realization principle is to be pictured as 'merely a concession made to the exigencies of a given situation'. ${ }^{39}$ In particular, two reasons are acknowledged in support of this 'rule of convenience ${ }^{40}$ First, the realization principle is deemed necessary because a tax on an increase in value without realization raises liquidity problems. Under a mark-to-market approach the event triggering the tax (the passage of a year and the increase in value) does not generate cash to pay the tax. ${ }^{41}$ Consequently, taxes on accrued market values force taxpayers to sell their assets or to borrow money. ${ }^{42}$ Second, a tax on accrued values requires an annual valuation of one's assets. In the absence of any actual receipt, tax administrators need to assess-and prove-the precise net value of one's gains. Moreover, many tax scholars recognize the difficulty and cost for tax authorities to monitor the market value of one's assets on a yearly basis. ${ }^{43}$ Additionally, a market assessment might be difficult for some goods and might lead to much dispute with the tax authorities. ${ }^{44}$ Hence the realization principle lingers on in most parts of our income tax systems.

Dominant income tax theory balances the ideals of a mark-to-market approach and the reality of the above-mentioned 'concession'. Researchers nonetheless plead for a prudent shift towards market assessment. In this regard, scholars are trying to convince policymakers that the taxation of value fluctuations would disturb taxpayers' affairs less than the liquidity argument assumes. ${ }^{45}$ Concerning the valuation problem, proponents of the mark-to-market approach believe that for most assets a stable,

\footnotetext{
36 This advantage is further discussed by Engler and Knoll; see Mitchell L. Engler and Michael S. Knoll, 'Simplifying the Transition to a (Progressive) Consumption Tax', 56(53) Southern Methodist University Law Review (2003) 53-81.

${ }^{37}$ Kwall, n. 27, 93.

${ }^{38}$ For confirmation of the non-normative nature of the realization principle, see Mitchell L. Engler, 'A Progressive Consumption Tax for Individuals: An Alternative Hybrid Approach', 54 Alabama Law Review (2003) 1210; Mary L. Heen, 'An Alternative Approach to the Taxation of Employment Discrimination Recoveries under Federal Civil Rights Statutes: Income from Human Capital, Realization, and Nonrecognition', 72 North Carolina Law Review (1994) 549-618; Stephen B. Land, 'Defeating Deferral: A Proposal for Retrospective Taxation', 52(1) Tax Law Review (1996) 45-118.

39 Thomas Reed Powell, 'The Constitutional Aspects of Federal Income Taxation', in Haig (ed.), n. 28,65 .

${ }^{40}$ Schenk, n. 27, $358 . \quad{ }^{41}$ Kwall, 27, 98.

${ }^{42}$ See, for example, Brown, n. 30, 1560, in which he states: 'Accrual taxation presents serious problems of its own-the difficulty of valuing assets and possible taxpayer illiquidity.'

${ }^{43}$ David M. Schizer, 'Realization as Subsidy', 73(5) New York University Law Review (1998) 1594; Schenk, n. 29, 630 .

${ }^{44}$ See James Ripetti, 'Commentary: It's All About Valuation', 53(4) Tax Law Review (2000) 612.

${ }^{45}$ See Schenk, arguing that the liquidity problem is not considerable enough to justify realization: Schenk, n. 27, 360-436.
} 
established market price can be detected, and the issue is less insurmountable than previously assumed. ${ }^{46}$

\section{Towards a Deontological Defence of the Realization Principle}

If the Piketty revolution results in concrete political eagerness to adopt a more ambitious tax on income from capital, the previous section has already outlined a theoretic consensus on the ideal assessment method. Although much of taxation theory grants no direct priority to mitigate inequality, it nonetheless alerts us to the fact that the realization principle is a benefit for capital owners. ${ }^{47}$

Any tax (or redistributive) system relies on two questions: what should be taxed and how should it be measured? Assuming the appropriateness of an income tax, this chapter will try to deliver a deontological defence of the realization principle. By explicating the moral problems of a mark-to-market approach I supplement the debate on tax justice. Moreover, I underwrite the moral impermissibility of a capital gains tax based on this assessment technique. To the extent that it relies on market values, the conclusions concerning the valuation standard for income also shed light on the permissibility of a wealth tax. Furthermore, by showing that the right to autonomy delivers a normative basis for the realization principle, I wish to challenge the consensus in taxation theory that the principle has no normative foundations.

The approach exemplified here will be different to the traditional normative framework governing taxation theory. Taxation will not be primarily presented as a means to optimize economic outcomes, but will also be seen as a matter of justice-here understood as legitimate (i.e. morally permissible) coercion. Rather than finding an optimal taxation, the aim here is to uncover a just taxation-a taxation policy that is consistent with people's fundamental rights and liberties. The latter are here accepted as 'prerequisites for the legitimate exercise of democratic authority' and create moral boundaries for governmental action. ${ }^{48}$ Correspondingly, the sort of tax policies that are permissible depend on a prior analysis of people's rights over their holdings and their person. Importantly, as will be elaborated in Section III.F, the presented deontological framework does not disturb redistributive or efficiency-related reform, as it opens up strategies to revise the current interpretation of the realization principle.

This section will outline the constraints of the right to autonomy on the proper assessment standard of income. First, I will exemplify the common intuition of the

\footnotetext{
${ }^{46}$ Ibid., 365-70. See also Schmudde, mentioning the emergence of financial products that have a secure value: David Schmudde, 'Responding to the Subprime Mess: The New Regulatory Landscape for an Integrated Defense of Market Assessment', 14(4) Fordham Journal of Corporate \& Financial Law (2009) 711. For an integrated defence of the mark-to-market approach, see Shakow and Shuldiner, who conclude that 7.5 per cent of all assets would be hard to value: David Shakow and Reed Shuldiner, 'A Comprehensive Wealth Tax', 53(4) Tax Law Review (2000) 529.

47 The traditional prior aim of the dominant 'theory of optimal taxation' is to reduce inefficiencies and market distortions imposed by taxation. See, for example, Joel Slemrod, 'Optimal Taxation and Optimal Tax Systems', 4(1) Journal of Economic Perspectives (1990) 157-78. For an avowal on tax theories' disregard for relative inequality, see Bankman and Shaviro, n. 25, 455.

${ }^{48}$ John Tomasi, Free Market Fairness (Princeton: Princeton University Press, 2013), 76.
} 
presumption of liberty (III.A), after which I will provide a general conceptualization of autonomy (III.B). Next, I will present valorizations as a function of autonomy (III.C). From this I will deduce the problematic nature of general market prices as a basis for interpersonal comparisons, and will articulate the normative basis for the realization principle (III.D). Finally, I will outline how the presented theory relates to some concurring work in taxation theory (III.E) and defend its unification with other aims in an integrated approach (III.F).

\section{A. The Presumption of Liberty}

Stanley Benn raises the example of a person named Alan sitting on a public beach. He has a pebble in each hand and is enjoying splitting them. ${ }^{49}$ Benn asks us to envisage a second person, Betty, who prevents Alan from continuing his activity by handcuffing him or removing all the pebbles out of his reach. Benn notes that Alan would be within his rights to demand a justification from Betty, while Betty would not be within her rights to demand an explanation for Alan's pebble splitting. So while Alan might justifiably resent Betty's interference, Betty has no grounds for complaint against Alan. So if a third person were to observe this situation, she would not ask why Alan was splitting pebbles, but rather why Betty was preventing him from doing so.

Benn illuminates a basic asymmetry in our normative outlook: we seek justification not for why people act the way they do, but rather for why others would want to prevent them from doing so. The initial onus of justification lies not on the person acting but rather on the person interfering with those actions. Even if most people might find Alan engaging in a useless activity, they still think he is under no requirement to justify his actions. The onus lies on Betty, who will need to explain her justification for imposing restrictions on Alan's actions. This is exactly what Joel Feinberg calls presumption in favour of liberty: 'liberty should be the norm, [while] coercion always needs some special justification. ${ }^{\text {'50 }}$

Interestingly, we have this attitudinal bias in favour of actions for persons. Imagine Betty interfering with some pebbles on a beach, preventing them from flowing back into the sea. An observer would not be inclined to ask her why she is intervening in the lives of the pebbles in the same way that would be asked if she were preventing other people from acting as they want. The principle of nonintervention that follows from the presumption of liberty is one we apply when we deal with adult persons. As long as there are no compelling reasons to intervene, all people have a moral claim to do as they wish until some justification is offered for limiting their liberty. ${ }^{51}$ We do not ask why we can cross a border, why we can have consenting sexual contact, or why we can have the freedom to choose our occupation; rather, we would demand a justification if those liberties were curtailed.

\footnotetext{
49 Stanley Benn, A Theory of Freedom (Cambridge: Cambridge University Press, 1988), 87.

50 Joel Feinberg, Harm to Others (New York: Oxford University Press, 1984), 9.

${ }^{51}$ See Feinberg discussing some common justifications for intervention: Ibid., $10 \mathrm{ff}$.
} 


\section{B. The Right to Autonomy}

But why is this the case? Why does the onus of justification lie on the interferer, rather than on the people who are acting the way they are? Why is freedom the norm, and why are we not allowed to act with people in the same way as we act with objects, plants, and animals?

The answer to these questions is tied to a fundamental quality of persons: purposes. We do not lie in a particular place in the same way that a pebble lies somewhere. We do not go and swim in the sea for the same reason that a crab does so. We consider humans to be 'persons' because their existence is not merely the outcome of external stimuli, but is embedded in 'purposes that [their] actions [are] designed to promote..52 We distinguish ourselves from objects and animals in this world because our actions are the outcome of intentions connected to personal goals. According to Benn this phenomenology of 'personal causation' delivers the moral underpinning of our conception of 'natural persons.. ${ }^{53}$

The axiom underlying the presumption of liberty is thus connected with an understanding that each person acts purposefully. The purpose underlying our actions is to attain our goals and the intention to do so is our motivation. However, this in itself does not entail a prescriptive attitude: one may, for example, hold the political view that every person's goals - and thus also their distinctive actions-should be matched to one common end. We can find the foundation of the presumption of liberty when we grant positive moral status to each person as a purposeful entity. Indeed, the right to autonomy arises from a normative appreciation of each person having an end of his or her own, which consequently acknowledges each person's claim to act in the light of this.

Hence, autonomy should be understood as the normative embodiment of purposeful behaviour. So, from an understanding that all people have their own purposes, we delineate the axiomatic right to act and live according to these. The reason that we do not demand justification for how Alan is acting, but rather for why Betty is intervening with his actions, is because each person has a separate end, and all people have the right to live and act accordingly. ${ }^{54}$ In terms of autonomy, the focus lies not on the content of the act but on the fact that it counts as one's own.

The scope of one's rights is limited by the equal rights of one's fellow. Consequently, autonomy delineates a moral space around each person, which constructs the territory wherein interference is principally illegitimate. ${ }^{55}$ Traditionally, the 'moral space' that demarcates people's sovereign domain is constructed by their body, their mind, and their property. ${ }^{56}$ One's physical body parts, mental and physical capacities,

\footnotetext{
52 Geoffrey Brennan and Loren Lomasky, Democracy and Decision: The Pure Theory of Electoral Preference (Cambridge, UK: Cambridge University Press, 1993), 9.

${ }^{53}$ Benn, n. 49, 91.

${ }^{54}$ See also Gaus, who connects the presumption of liberty with a Kantian conception of moral autonomy: Gerald Gaus, 'The Place of Autonomy within Liberalism', in Joel Anderson and John Christman (eds), Autonomy and the Challenges to Liberalism: New Essays (Cambridge, UK: Cambridge University Press, 2005), 272-306.

${ }^{55}$ See Feinberg using a 'territorial model' to conceptualize autonomy: Feinberg, n. 50, $53 \mathrm{ff}$.

${ }^{56}$ Ibid., 54.
} 
knowledge, experience, and rightfully obtained external goods all form part of one's personal sphere, and can be used according to one's wishes in the pursuit of one's personal ends. ${ }^{57}$

The reason that we cannot forbid Alan to split pebbles or impose a religion on Betty, and that we oppose forced labour and prosecute rape, and even that we despise manipulation, is because we recognize each person as an embodied, a choosing being with the right to pursue his or her own distinctive purpose. This fundamental axiom discloses the underpinning of more specific principles, such as freedom of religion, freedom of speech, and the free movement of persons. But it is also the case that contract law (where people are only bound by consent) or the precepts of tort law (where people need to compensate for damage to another's sovereign domain) are an elaboration of the right of each person to live according his or her own ends.

\section{Valorizations as a Function of Autonomy}

The right to autonomy justifies the radical diversity in people's actions: people opt for different subjects of study, strive for different jobs, and develop different hobbies. People want different things because they have different goals and preferences, and the principle of autonomy defends this variety as a consequence of people's moral rights. This also entails consequences regarding goods. As stressed by one of the founding fathers of the theory of marginal utility, goods have no intrinsic value themselvespeople attribute value to their own ends and consequently carry this over to economic goods as a means of satisfying these ends. ${ }^{58}$ Given the fact that people have different goals and preferences, they will assign different values to the same goods. Because of people's divergent ends, they adopt distinctive standards of value (or 'utility'), which lead to different rankings. For someone who embraces rock and roll as the highest personal good, concerts might be the most important happening in a weekend, whereas another person might build his weekend around his football team. People's distinctive standards follow from their distinctive ends, which ultimately come down to their differing views on utility-and economically this leads to conflicting monetary valorizations. For the rock and roll fan, a $£ 500$ ticket to see the Rolling Stones might be a good buy, whereas a classical music adept might deride this price as a sign of the aesthetic decline of our times. Someone might consider the price of petrol to be absurd, given his preference for public transport, whereas a keen motorbiker might perceive it as a small price to pay for the feeling of liberty she gets from riding her motorbike. If everybody had the same goals and preferences then everybody would buy the same products, and goods sold to equally wealthy people would end up being the same

\footnotetext{
57 The rights over one's body, mind, or external property do not necessarily involve the full right to income, so income taxation is not necessarily a violation of the sovereign domain. See, for example, Peter Vallentyne, 'Taxation, Redistribution and Property Rights', in Andrei Marmor (ed.), The Routledge Companion to Philosophy of Law (New York: Routledge, 2012), 291-301. For an elaboration of the difference between control and income ownership, see John Christman, The Myth of Property: Toward an Egalitarian Theory of Ownership (New York: Oxford University Press, 1994), 129-35.

${ }_{58}$ Carl Menger, Principles of Economics, James Dingwall and Bert F. Hoselitz (eds and trans) (Glencoe: The Free Press, 1950), 116.
} 
price. Yet people assign different valorizations to goods and services, which reflect their different views on well-being flowing from their respective ends. For one person the $£ 500,000$ salary of a stockbroker would not compensate the missed opportunity to follow her natural calling to be an academic, whereas being a stockbroker might be another person's dream job, and he would gladly accept half that salary to be able to do it. We thus see that the valorizations we attach to goods are a function of our autonomy.

From the perspective outlined here, market prices have no 'objective' status. Although in our everyday lives we see fixed prices as secure features of goods and services, these should rather be seen as compressions of different valorizations that people give to goods. Moreover, the market price is the aggregate of the valorizations of all the consumers in a market. ${ }^{59}$ As George Stigler makes clear, these can be conceived as an election result, whereby everybody has some minimal influence on the outcome, even though the result does not reflect anyone's valorizations. ${ }^{60}$ The high wages of many football players and the low prices (compared to production costs) of academic books are signs of general consumer preferences in society, yet they do not reflect any individual valorizations. My personal ranking might put the purchase of an academic book much higher than obtaining a football ticket. Similarly, the low prices for real estate in the countryside express society's general preference to live in the city, but obviously individuals can have the opposite ranking of value.

General prices therefore do not tell us anything about the utility standards of potential suppliers. The high prices for corporate tax lawyers indicate the high value that many businesses attach to fiscal analyses. These do not spell out the value standard of a particular lawyer, who might prefer to deliver academic services for an average wage. And the high price of renting modern apartments in city centres merely informs us about the preferences of urban citizens and businesses to live or work in apartmentsit does not give us any indication about the utility standards of the owners of these apartments, who might have completely different plans.

However, at the moment of effective consent over an amount of money in exchange for goods or services, prices transform into something that is more than sociological (the general market price) or psychological (a particular offer in an individual setting); they become information about people's utility standards. A consented price is a confirmation that a particular amount of money is seen as a valid valorization according to one's own utility standards. The fact that I effectively purchase an academic book confirms that I find this good valuable and I perceive the price as acceptable in view of my ends. And the fact that I accept a 'high' price for a house in the countryside counts as a confirmation of its value in the light of my somewhat deviant living preferences. So with regard to income, when the tenant of the city centre apartment effectively accepts the high rental price, she confirms this amount of money as a valid price according her own utility standards. If the well-established academic changes his profession because of a changed purpose (e.g. if he now has a family and wants to provide them

\footnotetext{
59 See Hayek identifying a price as a result of how people valorize the same things differently: Friedrich Hayek, The Mirage of Social Justice (London: Routledge and Kegan Paul, 1976), 76.

${ }^{60}$ For prices as a result of individual consumer votes, see George Stigler, The Theory of Price (New York: Macmillan, 1987), 12.
} 
with as high a standard of living as possible), he confirms the high price for corporate tax services as an appropriate benefit within his own standards of value.

To summarize, we can say that because people all have ends of their own, they will also have value standards of their own. Consequently, the right to autonomy recognizes that each person has personal valorizations as a function of his or her own subjective ends. From this perspective we have to downgrade market prices as an aggregate of other people's standards. At the occurrence of an exchange of property or services for money, people express their subjective standards in terms of a quantifiable homogeneous commodity: money. ${ }^{61}$

\section{Autonomy and Taxation}

Alan is not only a fan of pebble-splitting: he also works as an engineer for a mediumsized company. Considering his love for his family and his appetite for holidays and weekends, he did not opt for the highest-paying opportunity. Each year he earns $£ 72,000$ with his mathematical skills. Besides this he owns an apartment that he uses for artists' exhibitions, for which he paid $£ 200,000$. Additionally, he invested $£ 20,000$ to support his best friend's company.

During the hot summer months, however, a number of people discover Alan's capital (including his human capital), and express their value standards regarding some of his means. When he comes back he finds several offers in his mailbox. First, the raised general market value of his apartment translated into an offer: a local investor wishes to give him $£ 400,000$ to buy it and rent it to small businesses. Second, his friend's company managed to sign up a new big client, resulting in a doubling of the value of his shares. As if the summer has not already been profitable enough for Alan, an engineering company has tracked him down and given him an offer of working in a management position, earning three times his current wage. Finally, Alan has quite an unusual blood type, and an Indian businessman with an identical blood type offers him $£ 1$ million to buy his kidney via an intermediate company that commercializes human organs.

\section{The mark-to-market approach}

Most tax scholars will agree that Alan will come home a 'richer' man: income equals an increase in value of one's holdings for a period of time, and tax codes should not remain blind to Alan's very lucrative summer. ${ }^{62}$ Concerning his external means, his shares undeniably went up $£ 20,000$ in value and the current market value of his

\footnotetext{
${ }^{61}$ As mentioned in Section III.F, the requirement of confirmation of a particular monetary benefit is not restricted to the sale or transfer of property.

${ }^{62}$ As mentioned above, for most tax scholars, a taxation of income merely demands an increase in market value. See, for example, Reed Shuldiner, 'Consistency and the Taxation of Financial Products', 70(12) Taxes (1992) 781, in which he states: 'The Haig-Simons definition of income, accretions to wealth plus the value of consumption, is generally accepted as an appropriate definition of income for purposes of a comprehensive income tax.' See also Schenk, where a global mark-to-market regime taxing accretions is presented as a normative ideal: Schenk, n. 30, 572-3.
} 
apartment of approximately $£ 400,000$ means an increase in value of 100 per cent compared with last year. An ideal income tax, as supported in the cited literature, would include an end-of-year economic appreciation of these assets and would attribute Alan a capital income of $£ 220,000$. A tax targeting the value of his human capital, however, would not be advocated by most tax scholars due to the inevitable problems with conducting a proper valuation and to the possible lack of liquidity; a structural mark-to-market approach would seem insurmountable. It is indeed difficult to assess the market price of one's skills, and taxpayers who do not use their greatest earning potential would often not have the means to pay their tax debt. In our current example these 'administrative' concerns are not at stake, however: Alan has no liquidity problems (he inherited several million pounds) and we have a perfect example of the market price of his bio-capital ( $£ 1$ million for his kidney and $£ 216,000$ for his mathematical skills).

Yet this analysis indicates that the absence of any valuation or liquidity problems does not overcome deeper normative objections concerning the automatic application of these market values in the assessment of income. From the perspective of autonomy, the challenge for the accretion-based tax is identical in all four of the above situations. As we saw, valorizations are a function of autonomy. The prices for Alan's kidney, apartment, and shares reflect the desires of others who want to acquire these means, and the price for his skills stems from people's wish to rely on his skills. All of these prices, however, conflict with Alan's own purposes: he does not perceive his kidney as a commodity and would not sell it at any price. He enjoys his current job and does not perceive three times his wage to be sufficient compensation for the loss of free time that the new job would entail. Likewise, he bought the apartment to cultivate his aesthetic passions and fund young artists, and the money the investor is willing to transfer does not fit into any of his plans. Finally, he sees his shares as a financial support for his friend, and so has no plans whatsoever to sell them; this rise in share value reflects the interest of other investors in the company rather than any of Alan's own interests.

The economist's view on taxation might stress the fact that Alan has come home to a new situation: given the valorizations for his apartment, shares, kidney, and skills his economic 'position' has changed. By contrast, the current subjectivist normative outlook would claim that nothing has changed for Alan; he has rejected all of these offers and has not altered any of his plans-these valorizations have no meaning from the perspective of his own utility standard.

Commencing from a viewpoint of people as active, choosing entities we can see that valorizations are embedded in a subjective life plan. Each price reflects particular decisions in the light of further ends, which are often unknown to others. Assigning valorizations that reflect decisions that one does not plan, and preferences that one does not hold, is incongruous to autonomy. Moreover, it defines one's tax liability according to a value standard that could be completely contradictory to one's own. In general, when we take market prices as the assessment basis for interpersonal comparisons, we ignore people's own vision of well-being and impose valorizations that are alien to their own. Under a mark-to-market approach, Alan's tax base is nothing more than a representation of what of others would like him to do; even if he had no 
liquidity problems, he would object to paying taxes on $£ 1$ million for his kidney, on $£ 216,000$ for his job offer, on $£ 20,000$ for his shares, and on $£ 200,000$ for his apartment. His objection would rely on the principle of autonomy, claiming that he was being assessed in terms of subjective utility calculations that were completely alien to the standards by which he governed his own life. The content of one's duties (the tax base) gets one-sidedly defined by prices reflecting other people's intentions over one's means. From the perspective outlined here, we can coin this practice as a heteronomous tax base: the taxpayer is being ordered to comply with fiscal duties on the basis of unconsented valorizations.

From this perspective, we can recast the commonly raised problems regarding a mark-to-market approach. The problem is not that one might not have the cash to pay one's tax debt, or that tax administrators might have a difficult time assessing a true market value. Rather, the fundamental problem is that there is no 'true value' in the sense that nothing has an intrinsic, objective value; consequently, mere market valorizations can conflict with one's own standards. When we grasp how this measurement technique attributes unconsented valorizations, the disturbing nature of the markto-market approach in the taxpayer's life, for example in terms of liquidity issues, is simply an unsurprising consequence.

In summary, our right to autonomy discloses our intuitive protest against a markto-market approach. Valorizations are a function of autonomy, and by calculating tax obligations on the basis of non-shared valorizations the market-to-market approach dictates the standard of the market and ignores people's own vision of well-being.

\section{The realization approach}

Imagine that Alan changes his life radically in a couple of years: he remarries and adopts an exuberant lifestyle after having lost half of his means due to the messy divorce with his ex-wife. His consumption now exceeds his income, but despite his hedonistic lifestyle he does not want to withdraw from his responsibility regarding his children, and so plans to finance their university studies. Given this situation, Alan decides to sacrifice his shares and apartment in order to be able to fund his two children's degrees. On top of this, he wants to maintain his high-flying lifestyle by acquiring an apartment in an upmarket neighbourhood.

Despite his need for money, he sells his shares back to his friend at 25 per cent below the market price for just $£ 30,000$. Since he is one of the few friends who supported Alan during the last two years, he perceives this as a nice way to thank him. Furthermore, he uses his excellent negotiating skills to sell his apartment at $£ 450,000$, exceeding its market value. Putting aside any maintenance costs that he may have incurred over the years, he realizes a profit of $£ 260,000$ following these transactions.

Contrary to the previous situation, this figure is not a general market price but a monetary benefit that Alan consented to by means of his own value standard. Each of the figures involved arises from particular intentions with respect to his purposes (paying for his children's studies, acquiring a new apartment, and thanking his friend). These figures do not reflect the estimations of what other people would want 
in order to acquire his means; rather, they resemble Alan's choices in the light of his subjective ends.

An appreciation of the right to live according to one's own purposes unravels the normative role of the realization principle. General prices reflect transactions and preferences that might or might not fit with one's ends. Real-life exchanges, on the other hand, consist of people's true actions whereby they exteriorize their own value standard. Consented prices are more than psychological information about other people's goals and preferences: they are confirmation of a particular valorization that is a function of autonomy. So the economic equilibrium reached when a person consents to a price reflects one's subjective preferences in terms of the most homogeneous and quantifiable commodity: money. The importance of the receipt of a benefit in exchange for the use or sale of property is that through this event people signal their utility standard in an observable way. The value of the realization principle is exactly that such a method does not invade one's tax liability on the basis of other people's valorizations; instead, it replicates a person's subjective valorizations as expressed in consented monetary benefits. By submitting one's own valorizations as administrative input for tax authorities, taxpayers are not forced to live-and pay taxes-according to market preferences. Instead, they are only required to pay a contribution according to their own value standard. The realization principle thus protects taxpayers' liability against external standards and guarantees that their obligations will be calculated in terms of their own utility calculations as expressed in market exchanges. Consequently, as the realization standard supervenes on their own consented valorizations, it will not impose any alien vision of well-being.

To summarize, we can state that the right to live according to one's own ends delivers normative justification for the generally reviled principle of taxation after realization. In particular, the right of each person to live according to one's own ends and preferences entails a duty for tax authorities not to impose any valorizations that one does not share. The moral status of the realization principle lies precisely in the fact that when people monetize certain assets and goods (such as via sales or transfers), they externalize their preferences in consented valorizations. So the realization event, meant as the contractual confirmation of a certain monetary benefit, is more than the point in time when one 'effectuates one's prior economic income' (i.e. when an asset merely increases in value) ${ }^{63}$ it is the morally decisive turning point when one confirms a price or offer as being consistent with one's ends. In the absence of any general objective measure of utility, monetization yields a confirmation of valorization according to a person's own standard. Before such a moment, tax authorities fail to have any reliable information on a person's preferences and valorizations, and will fail to construe a tax base without violating the autonomy principle. As the realization principle supervenes on one's own consented valorizations, it consolidates the taxpayer's own view on well-being within the domain of income tax.

${ }^{63}$ For such an apprehension of income occurring irrespective of any realization, see for example, Kwall, n. 27, 80; Brown, n. 30, 1559-1680; Shakow, n. 30, 1111-205. 


\section{E. Personal and Market Goods}

In an excellent article Ilan Benshalom and Kendra Stead make a distinction that might have come to the reader's mind by now. On the one hand, they picture 'investment goods' like portfolio holdings and company shares; for these 'emotionally nonfungible assets' they state that it is 'reasonable to assign tax liability for that asset's fluctuation in value according to a mark-to-market regime. ${ }^{64}$ Aiming at an equal taxation of increased well-being (as measured by welfare), the authors qualify the market price as a good proxy. On the other hand, they envisage personal goods like inherited jewellery, self-created artwork, residential homes, and family businesses; for these goods they dismiss the mark-to-market approach as a 'bad proxy for well-being'. Moreover, the authors are convinced that for personal goods the taxpayer's 'subjective value is radically different (that is, significantly higher) than the assets' market value'. ${ }^{66}$ Consequently, deferral until the time of monetization is required here, since the effective market return serves as a better standard for the extracted welfare. Benshalom and Stead acknowledge that this partial realization principle would be an exemption that would cause distortions and inequities. ${ }^{67}$ Nevertheless, they note that personal assets represent a larger proportion of the wealth of low- and medium-income taxpayers than that of high-income taxpayers. Therefore, providing a tax benefit for personal assets would make the tax system as a whole more progressive. ${ }^{68}$

Benshalom and Stead's analysis is both illuminating and bold. In a clear fashion they identify both the aim of progressivity and the special character of personal goods as a normative bedrock for an exemption of these assets from the generally embraced mark-to-market approach. Nonetheless, for two reasons an overall defence of the realization principle can be found more convincing.

First, there is no general theory available that can provide policymakers with a comprehensive list that differentiates a small number of personal goods from the bulk of investment goods. As Benshalom and Stead acknowledge, the abstract distinction between personal and investment goods is in reality a continuum. ${ }^{69}$ However, no ordinal continuum can be established: even goods that the authors confidently put at the extremes can be ordered alternatively by individual taxpayers.

For instance, many young urban professionals perceive their home (qualified under 'personal goods') as their only form of financial investment. ${ }^{70}$ Consequently, their purchase will often reflect their anticipation of an increase in market value. Furthermore, families might perceive their family jewellery as a form of savings that could be sacrificed in the event of certain needs, such as university fees. Concerning the 'investment goods', generally, people might hold business shares and financial investments for financial reasons, yet it is not clear-cut that their market value will always coincide with people's personal value standards. Many shareholders who help to establish a company will have an emotional affiliation with its economic philosophy and produced goods that will transcend purely economic figures. Regarding investment

\footnotetext{
${ }^{64}$ Ilan Benshalom and Kendra Stead, 'Realization and Progressivity', 3(1) Columbia Journal of Tax Law (2011) 43-85, 68.

${ }^{65}$ Ibid., 66.

${ }^{66}$ Ibid., 64 (my emphasis).

${ }^{69}$ Ibid., 68.

67 Ibid., 69.

70 Ibid., 65.

68 Ibid., 69.
} 
portfolios, there are a rising number of people who combine the pursuit of profit with nonfinancial incentives, thereby obtaining portfolios that also reflect ethical, social, and ecological purposes. Such assets are not easily fungible with their more commercial counterparts, and the market value is not the sole standard by which people valorize these assets. Furthermore, Benshalom and Stead qualify family businesses as personal goods. Nonetheless, many of these tend to be sold to bigger entities, and many large companies arise from family businesses, so this does not seem to exclude the relevancy of market value as such. Conversely, many small businesses without any familial character-which the authors perceive as investment goods-do have personal value. Moreover, as the authors acknowledge, most goods fall between both extremes, and it will consequently be arbitrary to qualify them as one or the other. ${ }^{71}$

In other words, the reasons to reject a partial realization principle are similar to the reasons to reject the mark-to-market approach: the list of investments and personal goods upheld by policymakers and regulations will be incongruous to autonomy. The imposed distinction between market and personal goods will contain a standard of value that will often be inconsistent with the viewpoint of individual taxpayers and their ends. Many taxpayers will be taxed on the market value of goods that they hold for divergent reasons, and investors will obtain comparative benefits using the realization-based tax for so-called 'personal goods. ${ }^{72}$ The optimal decision from the viewpoint of autonomy is to put the authority over the distinction between both types of goods with the taxpayers themselves rather than with the legislator. When people agree on the receipt of a monetary benefit (via a market exchange), they signal that goods are fungible and so provide administrators with a valorization that adheres to their personal value standard (i.e. the agreed price). Additionally, given the fact that people's intentions are multidimensional (e.g. Alan selling his shares to his friend) and that most goods are partly personal and partly financial, the exact agreed price serves as the best reflection of people's ends and consequent value standards.

Second, the right to autonomy serves as a better explanation for our moral resistance to a mark-to-market approach than the reasons suggested by Benshalom and Stead. Envision once more Alan's apartment, which went up $£ 200,000$ in market value and became worth $£ 400,000$. His neighbour, who held a similar apartment, wished to rely on this price and sold it to a law firm. Alan, however, wanted to continue to use his apartment to accommodate young artists and their innovative exhibitions (prior to the break-up of his first marriage). He resented the reasons underlying the increased price (the corporate trend invading the neighbourhood) and perceived his decision as a way of rebelling against it. Our intuition tells us that it would have been very unjust to tax Alan on this increased market value. However, the real reason that we do not support Alan being taxed at a capital gain of $£ 200,000$ cannot lie in the fact that he attributed a 'higher value' to it than the current $£ 400,000$, as Benshalom and Stead endorse. This presumption would, for example, mean that he would be willing to pay a price for the apartment that exceeds this $£ 400,000$. But it could be perfectly possible that Alan would never consider buying his apartment at its current market price.

\footnotetext{
${ }^{71}$ Ibid., $68 . \quad{ }^{72}$ The authors forecast these malpractices in Ibid., 82.
} 
Furthermore, the assumption of a higher market value does not justify our intuitive position against taxing Alan. If anything, it provides a mandate for taxing him at this higher value rather than not at all. ${ }^{73}$

The proper theoretical explanation as to why we should refrain from taxing Alan on the increased market value is because a price supervenes on the taxpayer's intention to sell or rent an asset. The attribution of a certain amount of money presumes the relevancy of a specific market exchange within the subjective life plan of the person. However, in the absence of any real exchange we have no proof that this valorization will be consistent with any of the person's ends. The reason that we oppose Alan being taxed on the increase of $£ 200,000$ is because this price arises from plans that Alan did not intend to undertake, and consequently tied him to these external purposes. At the time, Alan held a deviant preference and the market value was inconsistent with his ends. So the reason that we oppose attributing income in the absence of real financial gains for these personal assets is not because the market value is a 'bad' proxy-it is because it is simply no proxy at all. Alan's preferences lay on a metric of value that was not expressible in any market price, since he did not engage in any market transactions. Any market valorization would have been incongruous to his autonomy, as it would have imposed a value standard that was contradictory to his own.

\section{F. Autonomy-Friendly Optimization of Income Tax}

I have tried to demonstrate that the realization principle is more than a pragmatic element: the logic that persons are taxed only when agreeing to the receipt of benefits can be seen as elucidating the right to autonomy. When tax scholars and egalitarian reformers aim at the optimal taxation of capital, such an endeavour ought to be implemented within the boundaries set by people's right to autonomy-that is, with respect for the realization principle.

As mentioned in Section II, the realization principle is nonetheless associated with practices such as the strategic trading and timing of asset dispositions, portfolio adjustments, and debt-financed consumption. These result in a decrease of the effective rate on capital-owners, causing inefficiencies and-among many other factors-adding to the accumulation of wealth, which egalitarian tax reformers wish to mitigate.

The theoretic framework elaborated here does not aspire to ignore these problems. Conversely, a renewed analysis can yield benefits in terms of how to deal with current defects. The realization principle protects taxpayers from liability for unconsented valorizations, not from taxation as such. Although the current contribution curtails authorities' taxing competences to some extent, it is not hostile to the promotion of efficiency or redistribution. Rather, an appraisal of the purpose of the realization principle can help to revise its current application in the light of these aims. Once we understand that confirmation of a certain monetary benefit is the prerequisite for an income tax, we can then begin to address its current problematic by-products.

\footnotetext{
73 The granted exemption for personal goods is thus merely founded on the aim of progressivity, rather than on a higher attribution of value.
} 
For instance, capital cannot only be sold or rented, but can also be applied to finance the acquisition of new goods by serving as security for a loan. One of the corollaries of the current income tax system is its disregard for the resulting debt-financed consumption or investment. Alan can put his apartment at risk and utilize its market value to borrow money to acquire a new apartment-without paying any income tax. If taxation is only triggered by a net cash flow, then taxpayers can utilize their assets to acquire loans, which allow them to consume or invest untaxed money. Most fiscal regimes thus permit taxpayers to enjoy the benefits of capital in the form of borrowed money used for consumption or investment, without being subject to income tax. Not only does this circumvention entail inefficiencies, but McCaffery also considers it to be a failure of the income tax 'to reach the propertied classes. ${ }^{74}$

A renewed understanding of the realization principle provides insights to foreclose this inequitable tax advantage that is often enjoyed by more affluent taxpayers. In a secured debt agreement people can utilize their assets in a commercial exchange, whereby an asset is being collateralized in order to obtain a loan. Collateralization refers to an asset's market value, which serves as a security measure in case of default. Within such contracts a capital owner thus agrees to the market value of an asset. To the extent that this value exceeds the initial purchase price, this qualifies as the receipt of a particular monetary benefit. So, if Alan mortgages his apartment to acquire a loan from the bank, he forfeits his initial protection from non-shared valorizations-and the condition for permissible taxation of the occurred gain is therefore fulfilled.

In summary, tax scholars' righteous objectives of equity and efficiency could be unified in a research project on an autonomy-friendly income taxation of capital, which would demand confirmation of a particular monetary benefit as a moral condition for taxation. However, this condition is not restricted to current applications of the realization principle. For instance, the utilization of an increased market value of capital in the conclusion of a secured loan can be qualified as a realization event. Consequently, when one's assets are being used as security for a loan, this permits capital gains taxation in an autonomy-friendly fashion. Rather than being the unilateral attribution of a market value, such taxation merely replicates the market value appropriated by the parties in an agreement. Additionally, by broadening capital-owners' tax base, this measure would increase the progressive nature of our tax system, as demanded by Piketty and others.

\section{Conclusion}

Thomas Piketty stated that taxation is 'not a technical matter, but preeminently a political and philosophical issue, perhaps the most important of all political issues' ${ }^{75} \mathrm{My}$ analysis has advanced this insight and tried to implement a concept from moral and political philosophy to the domain of income tax. From the right of each person to live according to his or her own purposes I have codified a particular conceptualization of income. Moreover, I have shown that authorities cannot measure one's income with

\footnotetext{
${ }^{74}$ See McCaffery, n. 31, 888. $\quad{ }^{75}$ See Piketty, n. 15, 493.
} 
alien utility standards, and should instead rely on shared valorizations. The fact that a mark-to-market approach leads to liquidity problems is merely the tip of the iceberg in this matter. I have demonstrated that a general market price often arises from exchanges that conflict with one's own purposes. Consequently, the attribution of this valorization ignores a person's own view on well-being, as it dictates the utility standard of the market. The value of the realization principle lies exactly in the fact that such a technique integrates with a person's autonomy, as it copies a person's consented monetary benefits within exchanges into the tax base.

By integrating normative insights from exterior domains, the current contribution has revealed a possible foundation for what is commonly described in taxation theory as a necessary evil. By clarifying acceptance over a monetary benefit as a moral prerequisite for income taxation, my deontological approach has tried to induce tax reformers to accomplish their aims within the boundaries of the realization principle, and to refute wealth and income taxation by means of a mark-to-market approach. Given this, I have presented the normative framework established here as not being hostile to egalitarian or efficiency-related perspectives. Rather, it is an appraisal of the right to autonomy as the proper foundation for the realization principle, which facilitates variations in its current interpretation in order to address the defects of the prevailing taxation of capital. An understanding of the normative bedrock of the realization principle, for example, underwrites the taxation of collateralized capital-a measure corresponding with the egalitarian aim of rendering our tax codes more progressive. 